\title{
Identifying supportive care needs of women with ovarian cancer
}

by Margaret I. Fitch and Rose Steele

\section{Abstract}

Women diagnosed with ovarian cancer may experience many shortterm and long-term effects from cancer and its treatment. Cancer has more than a physical impact, yet there is a lack of information about the types of needs these women have and whether they want help in meeting their needs.

The main purpose of this cross-sectional, descriptive study was to identify the supportive care needs (physical, emotional, social, informational, spiritual, psychological and practical) of women with ovarian cancer who attended a comprehensive, outpatient cancer centre. A further purpose was to determine if women wanted assistance in meeting those needs.

A total of 50 women diagnosed with ovarian cancer participated in this study by completing a self-report questionnaire (The Supportive Care Needs Survey). The data indicated that a range of supportive care needs remained unmet for this patient group. Eight of the top 10 most frequently reported needs were psychosocial, such as fears about the cancer returning or spreading. The women also expressed a range of difficulty in managing their needs. However, despite this reality, significant numbers of women indicated they did not wish to have assistance from the clinic staff with some needs. Suggestions for practice and future research are offered to assist oncology nurses in providing care to these women.

\section{Dégager les besoins en soins de soutien des femmes atteintes d'un cancer ovarien}

\section{Abrégé}

Les femmes diagnostiquées d'un cancer de l'ovaire subissent les nombreuses conséquences à court et à long terme du cancer et de son traitement. L'impact du cancer ne se limite pas à la sphère physique et pourtant, il existe fort peu d'information sur les types de besoins de ces femmes et si elles souhaitent ou non recevoir de l'aide afin de répondre à leurs besoins.

Le but principal de cette étude descriptive transversale était de cerner les besoins en soins de soutien (physiques, affectifs, sociaux, informationnels, spirituels, psychologiques et pratiques) des femmes atteintes d'un cancer ovarien qui fréquentaient en ambulatoire un centre de cancérologie intégré. Un but additionnel de l'étude était de déterminer si les femmes voulaient recevoir de l'aide afin de satisfaire ces besoins.

Cinquante femmes diagnostiquées d'un cancer de l'ovaire ont participé à cette étude en remplissant un questionnaire d'autoévaluation (enquête sur les besoins en soins de soutien). Les données indiquaient qu'un éventail de besoins en soins de soutien demeuraient insatisfaits chez ce groupe de patientes. Huit des dix besoins les plus fréquemment signalés étaient de nature psychosociale comme la crainte que le cancer ne revienne ou ne se propage. Les femmes ont également exprimé une gamme de difficultés sur le plan de la prise en charge de leurs besoins. Toutefois, cette réalité n'empêchait pas un nombre important de femmes d'indiquer qu'elles ne désiraient pas recevoir l'aide du personnel de la clinique relativement à certains de ces besoins. Des suggestions relatives à la pratique et aux recherches à réaliser à l'avenir sont offertes en vue d'aider les infirmières en oncologie à prodiguer les soins à ces femmes.
Ovarian cancer is the fourth leading cause of cancer-related death for women in Canada. An estimated 2,500 new cases of ovarian cancer and 1,700 deaths from the disease were expected in 2008 (National Cancer Institute of Canada, 2008). Women with ovarian cancer may face particularly difficult situations involving distress because of the aggressive surgical procedures used in treatment together with the toxic chemotherapy regimens (Armstrong, 2002; Pignata, Ballatori, Favalli, \& Scambia, 2001). At present, there is a lack of knowledge about the supportive care needs of these women.

Nursing staff in the gynecological clinic of a comprehensive, ambulatory cancer care centre in Ontario, Canada, were interested in understanding the supportive care needs of women with ovarian cancer attending the clinic. The staff wanted to provide optimal care to these women and were eager to further their knowledge about women's unmet needs. Although the nurses had a sense of what women needed, there was very little empirical research to support their beliefs. This study was developed to address this gap in evidence.

\section{Literature review}

Ovarian cancer has a profound and variable course characterized by an initial response to antineoplastic therapies, followed by relapse and progression of disease. As a result, the disease has a significant physical and emotional impact on women and their families (Fitch, Deane, \& Howell, 2003; Fitch, Gray, \& Franssen, 2001; Howell, Fitch, \& Deane, 2003a, 2003b). Some researchers have described this impact on quality of life (Bezjak et al., 2004; Ersek, Ferrel, Dow, \& Melancon, 1997; Ferrell et al., 2005; Fish \& Lewis, 1999; LockwoodRayermann, 2006; Schulman-Green, Ercolano, Dowd, Schwartz, \& McCorkle, 2008; Wenzel et al., 2002), while others have reported the symptom burden (Montazeri, McEwen, \& Gillis, 1996; Portenoy et al., 1994) and psychosocial distress experienced by this group of patients (Greimel \& Friedl, 2000; Hamilton, 1999; Wenzel et al., 2002). Relatively consistent findings have been reported: marked anxiety and depression have been observed in many women; sexuality was often negatively influenced; social functioning was impaired, especially as it related to the ability to go to work; and physical functioning and disease progression were often predictive of changes in quality of life. Women reporting the lowest quality of life were more likely to be younger, more educated, un-partnered, or living with advanced disease (Schulman-Green et al.). Frequently, data regarding ovarian cancer patients are subsumed within general gynecologic cancer studies (Bodurka-Bevers et al., 2000; Ell et al., 2005; Norton et al., 2004; Steele \& Fitch, 2008; Tobano, Condosta, \& Coons, 2002) and may not be specifically isolated.

Treatment for ovarian cancer may result in surgical morbidity and chemotherapy toxicities that are associated with severe neuropathy, changes in body image, altered relationships with partners and other significant persons in one's life, sexual concerns, and loss of fertility (Hoskins et al., 2005; Jenkins, 1998). Surgical treatment for pelvic cancers and oophorectomy or radiation/chemotherapy

\section{About the authors}

Dr. Margaret I. Fitch, RN, PhD, Head of Oncology Nursing and Co-Director of Patient and Family Support Program, Odette Cancer Centre, Sunnybrook Health Sciences Centre, Toronto, Ontario, E-mail: marg.fitch@sunnybrook.ca

Dr. Rose Steele, RN, PhD, Professor, School of Nursing, Faculty of Health, York University, Toronto, ON. 
ovarian ablation may result in dyspareunia. As many as $50 \%$ of patients treated for gynecologic cancer suffer from some type of sexual problem (Andersen \& Van Der Does, 1994). The symptoms associated with gynecological cancers and their often-invasive treatments have included unfavourable changes in sexual desire or fulfillment. These symptoms have been attributed to radiation tissue changes, early menopause, vaginal shortening, or change in one's body image (Hoskins et al.).

In an ethnographic study based on material obtained from seven years of correspondence among survivors of ovarian cancer and a support newsletter, Ferrell, Smith, Cullinane, and Melancon (2003) reported that the debilitating side effects of treatment were often worse than the disease itself. The most common symptom was pain, including peripheral neuropathy. Gastrointestinal problems such as nausea, diarrhea and constipation were also reported as frustrating. Symptoms of menopause, such as vaginal dryness and hot flashes, changes to menstrual patterns, and fertility issues were of concern to many women. Finally, women reported numerous other symptoms that negatively affected their quality of life, e.g., hearing loss, osteoporosis, tooth problems, skin conditions, appetite changes and sleep changes. Further analysis of these data demonstrated that spirituality was used both to make meaning of the experience and as a way of coping to positively impact women's quality of life (Ferrell, Smith, Cullinane, et al.).

Symptoms such as fatigue and pain are commonly reported with ovarian cancer and are experienced as having significant impact on daily living. In Ferrell, Smith, Juarez, and Melancon's (2003) study, fatigue was a problem because it reduced women's ability to continue with their daily responsibilities and they often felt they had insufficient energy to support their families. Donovan and Ward (2005) reported that 27 out of 49 women in their descriptive, correlational study identified fatigue as a distressing and uncontrollable symptom. More than half of the women (59\%) had not discussed fatigue with their health care providers at their last appointment and $56 \%$ reported that no professional had given them advice about how to manage fatigue. Donovan and Ward suggested that this lack of professional advice contributed to women's negative perceptions. Portenoy et al. (1994) found that pain was prevalent, especially for women with advanced disease. These researchers used a comprehensive pain scale to survey 151 women undergoing treatment for ovarian cancer. More than 50\% of the sample reported other symptoms, including fatigue, psychosocial distress, and insomnia, as well as pain. Management of the myriad symptoms is an important consideration in caring for women experiencing ongoing treatment and the resultant side effects (Lockwood-Rayermann, 2006).

Browall, Carlsson, and Horvath (2004) assessed information needs on nine items in a sample of 64 women who had been treated for ovarian cancer. Measurement took place three times: two to three weeks after diagnosis, when primary treatment was completed, and then six months after treatment finished. Informational needs about the disease and treatment options were ranked highest and showed little change across the three measurements. Information about psychosocial aspects and self-care were ranked lowest. Jefferies (2002) explored informational and emotional needs of 24 patients with ovarian cancer. She reported that $96 \%$ of participants had received verbal information, and almost two-thirds (66\%) had been given written information. However, $31 \%$ of the women found the written information severely lacking. The timing, amount, and delivery of information were important to the participants and $71 \%$ were satisfied with the timing, $83 \%$ with the amount, and $87 \%$ with the delivery of information. In a qualitative study, Howell et al. (2003a) reported that women with ovarian cancer $(n=18)$ wanted their care to be individualized and based on their own perceptions of what information they needed. Dialogue and ongoing conversations between patients and health care providers were seen as crucial, especially when dealing with recurrent ovarian cancer.
Psychosocial distress is a common experience for ovarian cancer patients, particularly during the time directly following diagnosis. Zabora, Brintzenhofeszoc, Curbow, Hooker, and Piantadosi (2001) reported that approximately $20 \%$ of these patients experience a significantly elevated level of distress after a new diagnosis. Psychosocial distress has also been noted for women during the screening process for ovarian cancer, during the diagnosis and treatment phase of illness, and at times of recurrence (Kornblith et al., 1995; Petersen, Graham, \& Qunlivan, 2005; Power, Brown, \& Ritvo, 2008; Robinson, Rosen, \& Bradley, 1997). High levels of anxiety and depression have been reported during chemotherapy treatment (Guidozzi, 1993; Kornblith et al.) with high distress scores continuing for one third of the long-term survivors of ovarian cancer (Ersek et al., 1997).

Anxiety was also documented in a qualitative study that explored patients' perspectives of being diagnosed and treated for cancer (Ekman, Bergbom, Ekman, Berthold, \& Mahsneh, 2004). Ten Swedish women were interviewed at diagnosis, during chemotherapy, and after chemotherapy was completed. The authors identified a need to support these women, as they learned how to cope with their anxiety. In her study, Jefferies (2002) found that women with ovarian cancer received emotional support from a variety of sources: family, friends, and health care professionals. Support groups were helpful for talking with other women in a similar situation and members gave each other emotional support. However, not all women liked support groups, especially when one of the members became ill or died.

Norton and colleagues (2004) reported that psychological stress, measured as anxiety, depression and loss of behavioural-emotional control, was present in many women with ovarian cancer $(n=143)$. Two structural equation models supported their hypotheses that perceived control and self-esteem are two mechanisms for explaining how illness-related and interpersonal stress may be associated with psychological stress among these women. Norton et al. (2004) argued that physical impairment leads to psychological stress for these patients because it erodes a sense of control. They also found that the unsupportive behaviours of family and friends resulted in lower selfesteem and higher psychological stress. It has been suggested that adaptive coping strategies, such as seeking adequate supportive care services, may help moderate the psychosocial distress of women with gynecological cancer (Lutgendorf et al., 2002; Norton et al., 2005).

It is clear that the multiple dimensions of the consequences of cancer and its treatment must be taken into account. However, while there is some research about the physical and psychosocial effects of ovarian cancer on women, the broad range of supportive care needs for this population has not been clearly identified. Further, there is a lack of information about whether or not women want help with their needs. Identification of these needs and desire for assistance is required to optimize care and positively impact women's quality of life.

\section{Purpose}

The ultimate goal of this work is to improve the quality of care provided to women with ovarian cancer. The immediate purpose of this cross-sectional, descriptive study was to identify the broad range of supportive care needs experienced by women with ovarian cancer attending a comprehensive, ambulatory cancer centre. A secondary purpose was to determine if patients wanted assistance in meeting those expressed needs.

\section{Method}

\section{Procedure}

Following ethical approval, all consecutive ovarian cancer patients attending the cancer centre's gynecological clinic over a four-month timeframe were approached to participate in the study. The approach was made in the reception area of the clinic by a research assistant who explained the study objectives and partici- 
pation to each patient. Those who agreed to participate signed a consent form and were given a self-report questionnaire to complete. If the patient completed the questionnaire while she was waiting for her appointment, it was collected by the research assistant. However, if the patient was unable to complete the questionnaire in that timeframe, the research assistant gave the patient a prestamped, addressed return envelope in which to return the questionnaire. Overall, a 49.3\% response rate was achieved.

\section{Data collection and analysis}

Patients completed a demographic form that had six questions: age in years; marital status (married/living with intimate partner, separated/divorced, widowed, single); highest level of education completed (no formal schooling, primary school, secondary or high school, college program, university program); month and year when cancer diagnosed and type of cancer (ovarian, vulva, endometrium, cervix, uterus, other); whether or not currently receiving treatment and, if not, then month and year of last treatment; and treatment received for the cancer (radiation, chemotherapy, surgery, other). Patients checked all that applied for the type of treatment question.

Patients also completed a questionnaire. The Supportive Care Needs Survey used in this study was based on an instrument that was developed and validated in Australia (Bonevski et al., 2000). The original tool contains 60 closed-ended items, and patients respond on a five-point scale. The scale reflects various levels of needs ranging from 1 = "No need", i.e., the item was not a problem for the patient as a result of having cancer, to $5=$ "Some need" with a high need for help, i.e., the item was of major concern or importance to the patient and the patient had a strong need for additional help with the problem or issue.

A principal components factor analysis (Bonevski et al., 2000) revealed needs grouped under five factors: 1) psychological-needs related to emotions and coping; 2) health system and informationneeds related to the treatment centre and information about the disease, treatment, and follow-up; 3) physical and daily living-needs related to coping with physical symptoms, side effects of treatment, and performing usual physical tasks and activities; 4) patient care and support-needs related to health care providers showing sensitivity to physical and emotional needs, privacy, and choice; and 5) sexuality-needs related to sexual relationships. Cronbach's alpha coefficients for the five factors ranged from 0.87 for sexuality to 0.97 for psychological. Four other items were not associated with a specific factor loading: transportation, other people's attitudes toward the patient, finances, and talking with other individuals.

The measurement tool can be readily comprehended by individuals with minimal education and can be completed in about 20 minutes (Bonevski et al., 2000). This tool had been revised within the cancer centre with a couple of groups: patients with lung cancer or advanced cancer who attended a palliative radiotherapy clinic at the centre. Reliability results for the lung cancer group were encourag-

Table 1. Supportive Care Needs SurveyGyne: Domains and Reliability Coefficients

\begin{tabular}{|l|l|l|}
\hline Domains & Number of Items & Cronbach's Alpha \\
\hline Emotional & 11 & 0.88 \\
\hline Spiritual & 7 & 0.87 \\
\hline Psychological & 11 & 0.85 \\
\hline Physical Symptoms & 14 & 0.85 \\
\hline Informational & 9 & 0.83 \\
\hline Social & 7 & 0.76 \\
\hline Practical & 8 & 0.63 \\
\hline
\end{tabular}

ing with subscales (the domains) reported at 0.66 to 0.90 , with $6 / 7$ being 0.80 or higher. For the palliative group, Cronbach's alpha ranged from 0.35 to 0.81 , with $5 / 7$ being 0.70 or higher. Pilot testing of the original tool had resulted in reordering of some questions for improved clarity. Slight wording changes were also necessary to reflect the current setting. For example, "hospital" was changed to "cancer centre." The revised tool also added a question about desire for help. For each item, patients also were asked to indicate if they wished to have help in dealing with the need (i.e., No, I do not want any help; Yes, I would like help; I feel uncertain about wanting help).

Prior to this current study, the revised tool underwent minor modifications by clinicians from the gynecological clinic in conjunction with the researchers. A few items were deleted and others were added to further adapt the tool so it was more relevant for this population. For example, "cough" was deleted and "vaginal discharge" was added. The resulting Supportive Care Needs Survey had 67 items that covered the seven domains of supportive care: emotional (11 items); informational (nine items); physical (symptoms; 14 items); practical (eight items); psychological (11 items); social (seven items); and spiritual (seven items). Face validity for this adapted tool was determined through acceptability to patients in the study population. Content validity was assured because the content of the questions was close to that of the original tool and experts had adapted it. For this gynecologic adaptation, the Cronbach's reliability coefficients for the need domains ranged from 0.63 to 0.88 with only one domain lower than 0.70 (see Table 1 ). Given the preliminary nature of working with this population, the tool was analyzed as a checklist only. Only surveys with no more than three unanswered questions were included in the analyses. For the purpose of this study, analysis was descriptive and focused on reporting item frequency.

\section{Results}

\section{Sample}

The average age for this convenience sample of 50 women was 59.4 years and was similar to the clinic population. Most patients were married $(\mathrm{n}=33)$, two-thirds had at least a college level education $(n=30)$, and 36 had been diagnosed for two years or less. Forty per cent were no longer on treatment $(n=20)$. The most common treatment was chemotherapy $(n=39)$ followed by surgery $(n=38)$ (see Table 2).

Table 2. Demographics $(n=50 *)$

\begin{tabular}{|c|c|c|}
\hline Age & $\begin{array}{l}<45 \text { years } \\
45-65 \text { years } \\
>65 \text { years }\end{array}$ & $\begin{array}{l}12 \\
13 \\
24\end{array}$ \\
\hline $\begin{array}{l}\text { Marital } \\
\text { Status }\end{array}$ & $\begin{array}{l}\text { Married } \\
\text { Separated/Divorced/Widowed } \\
\text { Single (Never Married) }\end{array}$ & $\begin{array}{l}33 \\
10 \\
7\end{array}$ \\
\hline $\begin{array}{l}\text { Educational } \\
\text { Level }\end{array}$ & $\begin{array}{l}\text { No formal schooling } \\
<\text { College } \\
\geq \text { College }\end{array}$ & $\begin{array}{l}1 \\
18 \\
30\end{array}$ \\
\hline $\begin{array}{l}\text { Length of Time } \\
\text { Since Diagnosis }\end{array}$ & $\begin{array}{l}<1 \text { year } \\
1-2 \text { years } \\
>2 \text { years }\end{array}$ & $\begin{array}{l}28 \\
8 \\
14\end{array}$ \\
\hline $\begin{array}{l}\text { Currently on } \\
\text { Treatment }\end{array}$ & $\begin{array}{l}\text { Yes } \\
\text { No }\end{array}$ & $\begin{array}{l}30 \\
20\end{array}$ \\
\hline $\begin{array}{l}\text { Treatment } \\
\text { Received }\end{array}$ & $\begin{array}{l}\text { Radiation } \\
\text { Chemotherapy } \\
\text { Surgery } \\
\text { Other }\end{array}$ & $\begin{array}{l}6 \\
39 \\
38 \\
2\end{array}$ \\
\hline
\end{tabular}




\section{Most frequently reported issues currently experienced}

Women reported currently experiencing issues across all seven domains and for all but one item. No one had an issue related to privacy rights in the clinic. The number of patients experiencing an issue ranged from $\mathrm{n}=1$ (physical-"vaginal discharge") to $\mathrm{n}=36$ (psychological-“fears about cancer returning"). In all domains there was at least one item where more than a quarter of the patients currently experienced an issue (see Tables 3 to 9 ).

Of the 10 most frequently reported, currently experienced issues, three were from the emotional domain (feelings of sadness, feeling down or depressed, worry that the results of your treatment are beyond your control). Two were physical (lack of energy, not being able to do things you used to do); two were psychological (fears about cancer returning, fears about cancer spreading); one was social (concerns about the worries of those close to you); one was spiritual (uncertainty about the future); and the other was practical (changes in usual routine and lifestyle) (see Table 10).

\section{Informational needs}

At the time of completing the survey, at least $25 \%$ of the women were experiencing an issue with three items in the informational domain: being informed about the things you can do to help yourself get well $(n=15)$, being informed about test results as soon as possible $(n=14)$, and being given explanations for those tests for which you would like explanations $(\mathrm{n}=13)$ (see Table 3$)$.

\section{Emotional needs}

At least $25 \%$ of women were currently experiencing emotional needs for six items: feelings of sadness $(n=25)$, worry that the results

Table 3. Informational needs $(\mathrm{N}=50)$

\begin{tabular}{|c|c|c|c|c|}
\hline Issue & $\begin{array}{l}\text { Currently } \\
\text { experiencing } \\
\text { issue }\end{array}$ & $\begin{array}{l}\text { Want } \\
\text { help }\end{array}$ & $\begin{array}{l}\text { Uncertain if } \\
\text { want help }\end{array}$ & $\begin{array}{l}\text { Want help } \\
\text { or are } \\
\text { uncertain/\%* }\end{array}$ \\
\hline To be informed about the things you can do to help yourself get well & 15 & 18 & 0 & $18 />100 \%$ \\
\hline To be informed about test results as soon as possible & 14 & 12 & 0 & $12 / 85.7 \%$ \\
\hline To be given explanations of those tests for which you would like explanations & 13 & 13 & 1 & $14 />100 \%$ \\
\hline To be informed about cancer that is under control or diminishing (in remission) & 10 & 11 & 0 & $11 />100 \%$ \\
\hline To be adequately informed about the benefits and side effects of treatment & 8 & 9 & 0 & $9 />100 \%$ \\
\hline To be informed about support groups in your area & 6 & 9 & 2 & $11 />100 \%$ \\
\hline To be given information about sexual relationships & 5 & 5 & 2 & $7 />100 \%$ \\
\hline To be given written information about important aspects of your care & 5 & 11 & 0 & $11 />100 \%$ \\
\hline $\begin{array}{l}\text { To be given information about aspects of managing your illness } \\
\text { and side effects of treatment }\end{array}$ & 5 & 12 & 2 & $14 />100 \%$ \\
\hline
\end{tabular}

Table 4. Emotional needs $(\mathrm{N}=50)$

\begin{tabular}{|c|c|c|c|c|}
\hline Issue & $\begin{array}{l}\text { Currently } \\
\text { experiencing } \\
\text { issue }\end{array}$ & $\begin{array}{l}\text { Want } \\
\text { help }\end{array}$ & $\begin{array}{l}\text { Uncertain if } \\
\text { want help }\end{array}$ & $\begin{array}{l}\text { Want help } \\
\text { or are } \\
\text { uncertain/\%* }\end{array}$ \\
\hline Feelings of sadness & 25 & 15 & 3 & $18 / 72.0 \%$ \\
\hline Worry that the results of your treatment are beyond your control & 24 & 10 & 0 & $10 / 41.7 \%$ \\
\hline Feeling down or depressed & 23 & 14 & 0 & $14 / 60.9 \%$ \\
\hline Anxiety about having any treatment & 22 & 11 & 2 & $13 / 59.1 \%$ \\
\hline Anxiety & 20 & 15 & 1 & $16 / 80.0 \%$ \\
\hline Feeling bored and/or useless & 17 & 10 & 0 & $10 / 62.3 \%$ \\
\hline To have one member of clinic staff with whom you can talk & 11 & 14 & 1 & $15 />100 \%$ \\
\hline To be treated like a person, not just another case & 10 & 5 & 2 & $7 / 70.0 \%$ \\
\hline Changes in sexual relationships & 9 & 4 & 4 & $8 / 88.9 \%$ \\
\hline $\begin{array}{l}\text { The opportunity to talk with someone who understands and } \\
\text { has been through similar experience }\end{array}$ & 8 & 9 & 1 & $10 />100 \%$ \\
\hline Clinic staff to acknowledge and show sensitivity to your feelings & 6 & 6 & 0 & $6 / 100 \%$ \\
\hline
\end{tabular}


of your treatment are beyond your control $(n=24)$, feeling down or depressed $(n=23)$, anxiety about having any treatment $(n=22)$, anxiety $(n=20)$, and feeling bored and/or useless $(n=17)$ (see Table 4$)$.

\section{Psychological needs}

Fears about cancer returning $(\mathrm{n}=39)$ and fears about cancer spreading $(\mathrm{n}=35)$ were the two top needs overall and were two of six psychological items experienced by at least $25 \%$ of the women. The other four were: learning to feel in control of your situation $(n=20)$, fears about pain $(n=20)$, fears about physical disability or deterioration $(n=19)$, and accepting changes in your physical appearance $(n=17)$ (see Table 5 ).

\section{Physical needs}

More than 25\% of patients expressed physical needs for six items: lack of energy $(n=28)$, not being able to do things you used to $(n=26)$, abdominal discomfort $(n=22)$, change in bowel pattern $(\mathrm{n}=19)$, not being able to work around the house $(\mathrm{n}=15)$, and change in appetite $(\mathrm{n}=14)$ (see Table 6$)$.

\begin{tabular}{|c|c|c|c|c|}
\hline Issue & $\begin{array}{l}\text { Currently } \\
\text { experiencing } \\
\text { issue }\end{array}$ & $\begin{array}{l}\text { Want } \\
\text { help }\end{array}$ & $\begin{array}{l}\text { Uncertain if } \\
\text { want help }\end{array}$ & $\begin{array}{l}\text { Want help } \\
\text { or are } \\
\text { uncertain/\%* }\end{array}$ \\
\hline Fears about cancer returning & 36 & 17 & 1 & $18 / 50 \%$ \\
\hline Fears about cancer spreading & 35 & 17 & 6 & $23 / 65.7 \%$ \\
\hline Learning to feel in control of your situation & 20 & 10 & 2 & $12 / 60 \%$ \\
\hline Fears about pain & 20 & 12 & 3 & $15 / 75.0 \%$ \\
\hline Fears about physical disability of deterioration & 19 & 10 & 1 & $11 / 57.9 \%$ \\
\hline Accepting changes in your physical appearance & 17 & 7 & 1 & $8 / 47.1 \%$ \\
\hline To have access to professional counselling if you or your family need it & 10 & 9 & 3 & $12 />100 \%$ \\
\hline Fears about losing your independence & 9 & 9 & 1 & $10 />100 \%$ \\
\hline Reassurance by the medical staff that the way you feel is normal & 7 & 8 & 0 & $8 />100 \%$ \\
\hline To be treated in a clinic that is as pleasant as possible & 5 & 6 & 0 & $6 />100 \%$ \\
\hline More fully protected rights to privacy when you are at the clinic & 0 & 0 & 0 & $0 / 0 \%$ \\
\hline
\end{tabular}

Table 6. Physical needs $(\mathrm{N}=50)$

\begin{tabular}{|c|c|c|c|c|}
\hline Issue & $\begin{array}{l}\text { Currently } \\
\text { experiencing } \\
\text { issue }\end{array}$ & $\begin{array}{l}\text { Want } \\
\text { help }\end{array}$ & $\begin{array}{l}\text { Uncertain if } \\
\text { want help }\end{array}$ & $\begin{array}{l}\text { Want help } \\
\text { or are } \\
\text { uncertain/\%* }\end{array}$ \\
\hline Lack of energy & 28 & 12 & 3 & $15 / 53.6 \%$ \\
\hline Not being able to do things you used to & 26 & 7 & 5 & $12 / 46.2 \%$ \\
\hline Abdominal discomfort & 22 & 10 & 4 & $14 / 63.6 \%$ \\
\hline Change in bowel pattern & 19 & 9 & 3 & $12 / 63.2 \%$ \\
\hline Not being able to work around at home & 15 & 3 & 2 & $5 / 33.3 \%$ \\
\hline Change in appetite & 14 & 4 & 2 & $6 / 42.9 \%$ \\
\hline Change in sexual feelings & 11 & 5 & 4 & $9 / 81.8 \%$ \\
\hline Changes in your ability to have sexual intercourse & 11 & 4 & 4 & $8 / 72.7 \%$ \\
\hline Changes in urinary function & 11 & 5 & 2 & $7 / 63.6 \%$ \\
\hline Pain & 9 & 6 & 1 & $7 / 77.8 \%$ \\
\hline Leg edema & 7 & 2 & 0 & $2 / 28.6 \%$ \\
\hline Nausea/Vomiting & 7 & 1 & 2 & $3 / 42.9 \%$ \\
\hline Clinic staff to attend promptly to your physical needs & 6 & 5 & 0 & $5 / 83.3 \%$ \\
\hline Vaginal discharge & 1 & 1 & 0 & $1 / 100 \%$ \\
\hline
\end{tabular}




\section{Spiritual needs}

Six items were current issues for at least a quarter of patients: uncertainty about the future $(\mathrm{n}=28)$, feelings about death and dying $(n=20)$, confusion about why this has happened to you $(n=19)$, keeping a positive outlook $(n=15)$, finding meaning in this experience $(n=15)$, and making the most of your time $(n=14)$ (see Table 7$)$.

\section{Social needs}

There also were five items in the social category that were experienced by more than 25\% of the women as current issues: concerns about the worries of those close to you $(n=29)$, concerns about fulfilling your role as a partner $(n=14)$, concerns about the ability of those close to you to cope with caring for

\begin{tabular}{|c|c|c|c|c|}
\hline Issue & $\begin{array}{l}\text { Currently } \\
\text { experiencing } \\
\text { issue }\end{array}$ & $\begin{array}{l}\text { Want } \\
\text { help }\end{array}$ & $\begin{array}{l}\text { Uncertain if } \\
\text { want help }\end{array}$ & $\begin{array}{l}\text { Want help } \\
\text { or are } \\
\text { uncertain/\%* }\end{array}$ \\
\hline Uncertainty about the future & 28 & 13 & 1 & $14 / 50 \%$ \\
\hline Feelings about death and dying & 20 & 8 & 6 & $14 / 70.0 \%$ \\
\hline Confusion about why this has happened to you & 19 & 8 & 3 & $11 / 57.9 \%$ \\
\hline Keeping a positive outlook & 15 & 10 & 2 & $12 / 80.0 \%$ \\
\hline Finding meaning in this experience & 15 & 7 & 2 & $9 / 60.0 \%$ \\
\hline Making the most of your time & 14 & 9 & 2 & $11 / 78.6 \%$ \\
\hline Clinic staff to convey a sense of hope & 11 & 5 & 1 & $6 / 54.5 \%$ \\
\hline
\end{tabular}

Table 8. Social needs $(\mathrm{N}=50)$

\begin{tabular}{|c|c|c|c|c|}
\hline Issue & $\begin{array}{l}\text { Currently } \\
\text { experiencing } \\
\text { issue }\end{array}$ & $\begin{array}{l}\text { Want } \\
\text { help }\end{array}$ & $\begin{array}{l}\text { Uncertain if } \\
\text { want help }\end{array}$ & $\begin{array}{l}\text { Want help } \\
\text { or are } \\
\text { uncertain/\%* }\end{array}$ \\
\hline Concerns about the worries of those close to you & 29 & 11 & 6 & $17 / 58.6 \%$ \\
\hline Concerns about the ability of those close to you to cope with caring for you & 19 & 9 & 4 & $13 / 68.4 \%$ \\
\hline Concerns about fulfilling your role as a partner & 14 & 8 & 2 & $10 / 71.4 \%$ \\
\hline Concerns about your caregiving role & 13 & 8 & 3 & $11 / 84.6 \%$ \\
\hline Changes in people's attitudes and behaviours towards you & 13 & 6 & 0 & $6 / 46.2 \%$ \\
\hline Talking to other people about the cancer & 3 & 4 & 1 & $5 />100 \%$ \\
\hline Family and friends to be allowed with you in the clinic whenever you want & 2 & 0 & 0 & $0 / 0 \%$ \\
\hline
\end{tabular}

Table 9. Practical needs $(\mathrm{N}=50)$

\begin{tabular}{|c|c|c|c|c|}
\hline Issue & $\begin{array}{l}\text { Currently } \\
\text { experiencing } \\
\text { issue }\end{array}$ & $\begin{array}{l}\text { Want } \\
\text { help }\end{array}$ & $\begin{array}{l}\text { Uncertain if } \\
\text { want help }\end{array}$ & $\begin{array}{l}\text { Want help } \\
\text { or are } \\
\text { uncertain/\%* }\end{array}$ \\
\hline Changes in usual routine and lifestyle & 25 & 12 & 0 & $12 / 48.0 \%$ \\
\hline Waiting a long time for clinic appointments & 15 & 7 & 1 & $8 / 53.3 \%$ \\
\hline Concerns about your financial situation & 10 & 6 & 3 & $9 / 90 \%$ \\
\hline Concerns about paying for prescription medications & 8 & 5 & 2 & $7 / 87.5 \%$ \\
\hline To be given choices about when you go for tests or treatments & 8 & 7 & 1 & $8 / 100 \%$ \\
\hline Concerns about getting to and from the clinic & 4 & 2 & 1 & $3 / 75.0 \%$ \\
\hline More choice about which clinic you attend & 2 & 1 & 0 & $1 / 50 \%$ \\
\hline
\end{tabular}


you $(n=19)$, concerns about your caregiving role $(n=13)$, and changes in people's attitudes and behaviours to you $(n=13)$ (see Table 8).

\section{Practical needs}

In this final dimension, at least $25 \%$ of patients expressed current needs in only two items: changes in usual routine and lifestyle $(n=25)$, and waiting a long time for clinic appointments $(n=15)$ (see Table 9).

\section{Self-reported distress linked with selected issues}

The women who were experiencing an issue were asked to indicate how much distress they were feeling because of a particular issue. The distress reported for each of the 10 most frequently reported items in terms of low, moderate and high intensity are presented in Table 10. Of note, in seven of the 10 items, high distress was reported for at least a quarter of those experiencing the issue.

\section{Help desired}

Women who were currently experiencing an issue were asked to indicate if they wished to have help in dealing with the need. The researchers assumed that anyone who was "uncertain" deserved at least further exploration of her possible or actual need in a conversation with staff. Therefore, numbers from those who reported "uncertain" were added to those who said "yes" and this total was divided by the number currently experiencing the issue. These calculations determined the percentages of people with an issue who wanted some type of help. However, in a number of instances, more women reported wanting help than had indicated they were actually currently experiencing the issue. Results from those who reported either "yes" or "uncertain" are also presented in Tables 3 to 9 .

A high percentage of women in this study wanted help with issues they were currently experiencing. In all but 10/67 items (more fully protected rights to privacy when at the clinic, not being able to work around the home, change in appetite, leg edema, nausea/vomiting, uncertainty about the future, changes in people's attitudes and behaviours towards you, accepting changes in your physical appearance, not being able to do the things you used to do, changes in usual routine and lifestyle, and worry that the results of your treatment are beyond your control), at least $50 \%$ of patients experiencing a need wanted help. The last three items were seventh, eighth, and ninth respectively on the top 10 currently experienced issues, but slightly fewer than $50 \%$ of women with a need in these areas wanted help. Interestingly, even though relatively few women were experiencing informational needs, virtually everyone who had a need in this area wanted help with it. Somewhat perplexingly, in 8/9 informational items, more women reported wanting help with an issue than were actually currently experiencing concerns about it. Similar results were found with three psychological items, two emotional items, and one social item.

\section{Discussion}

This cross-sectional study was undertaken to describe the full range of supportive care needs of women with ovarian cancer. Although the study was conducted in one setting and only had a reasonable response rate, the data provide an emergent picture of the potential level of need the patients in this population could be carrying at a point in time. Clearly, the women were experiencing more than physical needs and were experiencing a range of issues simultaneously. In addition, a sizeable proportion were experiencing high distress because of the issues they were trying to manage.

That the top 10 issues included needs in the emotional domain is not surprising (e.g., Norton et al., 2005; Zabora et al., 2001). In particular, a feeling of losing or not having control is supported by Norton et al. who hypothesized that decreased perceived control is correlated with higher psychological distress. Yet, health care systems tend to reinforce a lack of control, from patients having to wait for hours at an appointment to lack of choice in when and where to have tests and treatments. A patient-focused model of care in which patients and health care providers work as a team might help alleviate some of the current concerns about control.

Lack of energy (or fatigue) has been reported by other researchers (e.g., Donovan \& Ward, 2005; Ferrell, Smith, Cullinane, et al., 2003). Yet, there is enough accumulated evidence about fatigue and its management that health care providers should be offering patients suggestions to help them manage this symptom, especially

Table 10. Most Frequently Reported Items Across all Supportive Care Domains

\begin{tabular}{|c|c|c|c|c|c|c|}
\hline \multirow[t]{2}{*}{ Issue } & \multirow{2}{*}{$\begin{array}{l}\text { Currently } \\
\text { experiencing } \\
\text { issue }\end{array}$} & \multirow{2}{*}{$\begin{array}{l}\text { Want } \\
\text { help }\end{array}$} & \multirow{2}{*}{$\begin{array}{l}\text { Uncertain if } \\
\text { want help }\end{array}$} & \multicolumn{3}{|c|}{ Distress caused by issue } \\
\hline & & & & Low & Mod & High \\
\hline Fears about cancer returning (PS) & 36 & 17 & 7 & 12 & 15 & $9 *$ \\
\hline Fears about cancer spreading (PS) & 35 & 17 & 6 & 15 & 11 & $9 *$ \\
\hline Concerns about the worries of those close to you (SO) & 29 & 11 & 6 & 11 & 12 & 6 \\
\hline Uncertainty about the future (SP) & 28 & 13 & 1 & 14 & 7 & $7 *$ \\
\hline Lack of energy $(\mathrm{PH})$ & 28 & 12 & 3 & 11 & 10 & $7 *$ \\
\hline Not being able to do things you used to $(\mathrm{PH})$ & 26 & 7 & 5 & 10 & 10 & 6 \\
\hline Feelings of sadness (E) & 25 & 15 & 3 & 12 & 8 & 5 \\
\hline Changes in usual routine and lifestyle (PR) & 25 & 12 & 0 & 12 & 6 & $7 *$ \\
\hline $\begin{array}{l}\text { Worry that the results of your treatment are } \\
\text { beyond your control (E) }\end{array}$ & 24 & 10 & 0 & 13 & 5 & $6^{*}$ \\
\hline Feeling depressed or down (E) & 23 & 14 & 0 & 10 & 7 & $6 *$ \\
\hline
\end{tabular}


because women may be distressed if they do not have enough energy to maintain their usual roles (Ferrell, Smith, Juarez, et al., 2003). Communication about this issue needs to be improved and research efforts need to continue to develop and test interventions to decrease cancer-related fatigue.

An unexpected, but interesting result was the number of times where more women wanted help with an issue than were currently experiencing the issue. It is possible that the respondents were confused or misread the questionnaire. However, the researchers had not faced this discrepancy when using the tool with the two other populations at the same cancer centre. Perhaps the nature of this group (i.e., all women) influenced the results. Ekwall, Ternestedt, and Sorbe (2003) reported that information and ongoing dialogue with health care providers were very important to women with gynecologic cancer. A need for information also has been reported by Browall et al. (2004) and Jefferies (2002). As Beever (2004) pointed out, "patients need information for a variety of reasons" (p. 193) because cancer and its treatment have physical, social, psychological, emotional, practical and spiritual impacts that all require some form of information to help patients manage their lives. Future interventions ought to be designed to address all domains (OtisGreen et al., 2008; Power et al., 2008).

A sizeable proportion of women are distressed and need help. However, patients may need different interventions depending on how distressed they are (Zabora et al., 2001). Those at high risk need to be identified early so prospective interventions can be put in place to prevent distress (Schulman-Green et al., 2008). In contrast to the tool used in this study, a brief screening tool would likely be more acceptable to patients and providers, as a first step. More indepth assessment could be completed later based on the screening results. Whatever approaches are used, they must be feasible for use in a busy clinical setting.

Staff may need to adopt an approach of asking women in the waiting room to explain what their main issue is for the visit, as opposed to following the professional's agenda; what staff think is important may not be the most pressing issue for the woman. Such an approach would allow patients to focus before coming into the examination room and not be distracted from their main concerns. Computer technology has been used successfully in some settings to facilitate identification of issues (Carlsson \& Bultz, 2003; Linden, Yi, Barroetavena, MacKenzie, \& Doll, 2005). For example, a list of problems/issues is available on computers in the waiting area and patients complete the questionnaire using a touch-screen computer before their appointment. Results are shared immediately with the care team and used to offer relevant interventions following dialogue with patients. Interventions would need to be provided at the same time as the woman attends the clinic. Practice settings need to reflect upon how they currently deliver care and make appropriate accommodations (e.g., a change in staffing patterns) to allow for successful implementation of such a practice.

Psychosocial needs were most commonly identified in this current study, both with regards to being currently experienced and in wanting help. This finding suggests that current practice may be providing care for the physical issues, but the other components of supportive care still require some attention. Many of the top issues were psychosocial and areas may not be assessed in practice for a variety of reasons. For example, the focus of short outpatient clinic visits is often on the physical and staff may lack time, or perceive they lack time, to delve into psychosocial issues that are invariably complex and require excellent clinical skills. Given the busy nature of clinical environments and the current realities of staff shortages, the staff needs to be resourceful and innovative in how they provide information and care to patients. For example, consideration could be given to providing information via computers or videos in the clinic, or procedures could be established so that patients could ask for and receive information or advice via e-mail or the internet. In all instances, there needs to be a balance between providing broad information and offering the type of individualized information and care that would be most appropriate for a specific patient.

Clearly, there is a need to handle the broad range of supportive care needs, and that practice requires effective inter-professional teamwork. Currently, there are few care models in practice settings that successfully include the full range of disciplines. In addition, referral practices tend to be less than optimal, so patients can have difficulty accessing appropriate services. Processes need to be implemented that will ensure the referral process beyond the basic cancer care team, for example, to psychosocial experts, is as easy as possible. Finally, institutional programs may need to link with existing community-based programs to ensure optimal care across the cancer journey.

Quantifying supportive care needs is an emerging area of research. While some qualitative research has been completed (e.g., Ekman et al., 2004; Ferrell, Smith, Cullinane, et al., 2003; Power et al., 2008), there is very little quantitative, especially around whether or not people want help with their needs. This initial study is useful for pinpointing areas of concern and identifying potential areas for future research and development of interventions. For example, who do women want help from? What kind of help do they want? If they do not want help, why not? Are they getting help from elsewhere and, if so, from whom? Do they think that nothing can be done? Researchers need to ask women these and similar questions in future research. Different approaches to providing care based on gender may be required and clinicians need the evidence so that appropriate interventions can be developed.

\section{Conclusion}

Women with ovarian cancer may need help for a variety of unmet needs. Those needs should be identified early so interventions can be offered as quickly as possible. While lack of energy and not being able to do the things they used to do were issues for many women, the majority of the most frequently identified needs were psychosocial. Structures and processes need to be put in place to ensure a quick and easy identification of unmet needs that can be followed by immediate and adequate intervention. Further research is required to identify needs and the type of help that women desire, so appropriate interventions can be developed.

\section{References}

Andersen, B.L, \& Van Der Does, J. (1994). Surviving gynecologic cancer and coping with sexual morbidity: An international problem. International Journal of Gynecologic Cancer, 4, 225-240.

Armstrong, D.K. (2002). Relapsed ovarian cancer: Challenges and management strategies for a chronic disease. Oncologist, 7(Suppl. 5), 20-28.
Beever, K. (2004). Meeting the information needs of people with cancer [Editorial]. European Journal of Oncology Nursing, 8, 193-194.

Bezjak, A., Tu, D., Bacon, M., Isoba, D., Zee, B., Stuart, G., et al. (2004). Quality of life in ovarian cancer patients. Journal of Clinical Oncology, 22, 4595-4603. 
Bodurka-Bevers, D., Basen-Engquist, K., Carmack, C.L., Fitzgerald, M.A., Wolf, J.K., de Morr, C., et al. (2000). Depression, anxiety and quality of life in patients with epithelial ovarian cancer. Gynecologic Oncology, 78, 302-308.

Bonevski, B., Sanson-Fisher, R., Girgis, A., Burton, L., Cook, P., Boyes, A., et al. (2000). Evaluation of an instrument to assess the needs of patients with cancer. Cancer, 88(1), 217-225.

Browall, M., Carlsson, M., \& Horvath, G. (2004). Information needs of women with recently diagnosed ovarian cancer-A longitudinal study. European Journal of Oncology Nursing, 8, 200-207.

Carlsson, L.E., \& Bultz, B.D. (2003). Cancer distress screening: Needs, models and methods. Psychosomatic Research, 55(5), 403-409.

Donovan, H., \& Ward, S. (2005). Representations of fatigue in women receiving chemotherapy for gynecologic cancers. Oncology Nursing Forum, 32(1), 113-116.

Ekman, I., Bergbom, I., Ekman, T., Berthold, H., \& Mahsneh, S. (2004). Maintaining normality and support are central issues when receiving chemotherapy for ovarian cancer. Cancer Nursing, 27(3), 177-182.

Ekwall, E., Ternestedt, B., \& Sorbe, B. (2003). Important aspects of health care for women with gynecologic cancer. Oncology Nursing Forum, 30(2), 313-319.

Ell, K., Sanchez, K., Vourlekis, B., Lee, P., Dwight-Johnson, M., Lagomasino, I., et al. (2005). Depression, correlates of depression, and receipt of depression care among low-income women with breast or gynecologic cancer. Journal of Clinical Oncology, 23, 3052-3060.

Ersek, M., Ferrel, B.R., Dow, K.H., \& Melancon, C.H. (1997). Quality of life in women with ovarian cancer. Western Journal of Nursing Research, 19, 334-350.

Ferrell, B., Cuillinane, C.A., Ervine, K., Melancon, C., Uman, G.C., \& Juarez, G. (2005). Perspectives on the impact of ovarian cancer: Women's view of quality of life. Oncology Nursing Forum, 32, 1143-1149.

Ferrell, B., Smith, S., Cullinane, C., \& Melancon, C. (2003). Symptom concerns of women with ovarian cancer. Journal of Pain and Symptom Management, 25(6), 528-538.

Ferrell, B., Smith, S., Juarez, G., \& Melancon, C. (2003). Meaning of illness and spirituality in ovarian cancer survivors. Oncology Nursing Forum, 30(2), 249-257.

Fish, L.S., \& Lewis, B.E. (1999). Quality of life issues in the management of ovarian cancer. Seminars in Oncology, 25(Suppl. 1), 32-39.

Fitch, M.I., Deane, K.A., \& Howell, D. (2003). Living with ovarian cancer: Women's perspectives on treatment and treatment decision-making. Canadian Oncology Nursing Journal, 13(1), 8-13.

Fitch, M.I., Gray, R.E., \& Franssen, E. (2001). Perspectives on living with ovarian cancer: Older women's views. Oncology Nursing Forum, 28, 1433-1442.

Greimel, E.R., \& Freidl, W. (2000). Functioning in daily living and psychological well-being of female patients. Journal of Psychosomatic Obstetrics and Gynecology, 21, 25-30.

Guidozzi, F. (1993). Living with ovarian cancer. Gynecologic Oncology, 50, 202-207.

Hamilton, A.B. (1999). Psychological aspects of ovarian cancer. Cancer Investigation, 17, 335-341.

Hoskins, W.J., Pesez, C.A., Young, R.C., Baraket, P.R., Marlnan, J., \& Randall, M.W. (2005). Principles and practices of gynecologic oncology (4th ed.). Toronto, ON: Lippincott, Williams \& Wilkin.

Howell, D., Fitch, M.I., \& Deane, K. (2003a). Impact of ovarian cancer perceived by women. Cancer Nursing, 26(1), 1-9.

Howell, D., Fitch, M.I., \& Deane, K. (2003b). Women's experiences with recurrent ovarian cancer. Cancer Nursing, 26(1), 10-17.
Jefferies, H. (2002). Ovarian cancer patients: Are their informational and emotional needs being met? Journal of Clinical Nursing, 11(1), 41-47.

Jenkins, B. (1998). Patient reports of sexual changes after treatment for gynecological cancer. Oncology Nursing Forum, 15(3), 231-242.

Kornblith, A.B., Thater, H.T., Wong, G., Vlamis, V., Lepore, J.M., Loseth, D.B., et al. (1995). Quality of life of women with ovarian cancer. Gynecologic Oncology, 59, 231-242.

Linden, W., Yi, D., Barroetavena, M.C., MacKenzie, R., \& Doll, R. (2005). Development and validation of a psychosocial screening instrument for cancer. Health Quality of Life Outcomes, 3, 54.

Lockwood-Rayermann, S. (2006). Survivorship issues in ovarian cancer: A review. Oncology Nursing Forum, 33, 553-562.

Lutgendorf, S., Anderson, B., Ullrich, P., Johnsen, E., Buller, R., Sood, A., et al. (2002). Quality of life and mood in women with gynecologic cancer. Cancer, 94, 131-140.

Montazeri, A., McEwen, J., \& Gillis, C.R. (1996). Quality of life with ovarian cancer: Current state of the research. Supportive Cancer Care, 4, 169-179.

National Cancer Institute of Canada. (2008). Canadian cancer statistics 2008. Toronto, ON: Author.

Norton, T., Manne, S., Rubin, S., Carlson, J., Hernandez, E., Edelson, M., et al. (2004). Prevalence and predictors of psychological distress among women with ovarian cancer. Journal of Clinical Oncology, 22, 919-926.

Norton, T., Manne, S., Rubin, S., Hernandez, E., Carlson, J., Bergman, C., et al. (2005). Ovarian cancer patients' psychological distress: The role of physical impairment, perceived unsupportive family and friend behaviours, perceived control, and self-esteem. Health Psychology, 24(2), 143-152.

Otis-Green, S., Ferrel, B., Sun, V., Spolum, M., Morgan, R., \& MacDonald, D. (2008). Feasibility of an ovarian cancer quality of life psychoeducational intervention. Journal of Cancer Education, 23(4), 214-221.

Peterson, R.W., Graham, G., \& Qunlivan, J.A. (2005). Psychologic changes after a gynecologic cancer. Journal of Obstetrics and Gynecologic Research, 31(2), 152-157.

Pignata, S., Ballatori, E., Favalli, G., \& Scambia, G. (2001). Quality of life: Gynecological cancers. Annals of Oncology, 12(3), 37-42.

Portenoy, R.K., Kornblith, A.B., Wong, G., Vlamis, Y., Lepore, J.M., Loseth, D.B., et al. (1994). Pain in ovarian cancer: Prevalence, characteristics, and associated symptoms. Cancer, 74(3), 907-915.

Power, J., Brown, L., \& Ritvo, P. (2008). A qualitative study examining psychosocial distress, coping and social support across the stages and phases of epithelial ovarian cancer. Health Care for Women International, 29(4), 366-383.

Robinson, G.E., Rosen, B.P., \& Bradley, L.N. (1997). Psychological impact of screening for familial ovarian cancer: Reactions to initial assessment. Gynecologic Oncology, 65, 197-205.

Schulman-Green, D., Ercolano, E., Dowd, M., Schwartz, P., \& McCorkle, R. (2008). Quality of life among women after surgery for ovarian cancer. Palliative and Supportive Care, 6(3), 239-247.

Steele, R., \& Fitch, M.I. (2008). Supportive care needs of women with gynecologic cancer. Cancer Nursing, 31(4), 284-291.

Tobano, M., Condosta, D., \& Coons, M. (2002). Symptoms affecting the quality of life in women with gynecologic cancer. Seminars in Oncology Nursing, 18(3), 223-230.

Wenzel, L.B., Donnelly, J.P., Fowler, J.M., Habbal, R., Taylor, T.H., Aziz, N., et al. (2002). Resilience, reflection, and residual stress in ovarian cancer survivorship. Psycho-Oncology, 11, 142-154.

Zabora, J., Brintzenhofeszoc, K., Curbow, B., Hooker, C., \& Piantadosi, S. (2001). The prevalence of psychological distress by cancer site. Psycho-Oncology, 10, 19-28. 